\title{
TECHNOLOGY EDUCATION AT A CROSSROADS - HISTORY, PRESENT AND PERSPECTIVES
}

\author{
Jiř́ DOSTÁL*, Palacký University Olomouc, Czech Republic \\ Veena PRACHAGOOL, Mahasarakham University, Thailand
}

Přijato: 15. 3. 2016 / Akceptováno: 29. 3.2016

Typ článku: Teoretická studie

DOI: $10.5507 /$ jtie.2016.006

Abstract: The comparative study sees the issues of contemporary technology education in the international context. It notes the cultures of technology education in decline and a phenomenon called technical literacy paradox. Perspectives are delimited in the context of polytechnic principle and STEM concept. Based on the analysis, the extension of the term technology literacy of the emotional aspect is proposed. Based on the findings from abroad, the study presents the modern concept of technical instruction during the basic education. It is a broader understanding and it includes the industrial technology, construction technology, electrotechnology, ICT, transport technology, etc.

Key words: technology education, culture of technology education, STEM, technological literacy, technology literacy paradox, early childhood.

\section{TECHNICKÉ VZDĚLÁVÁNÍ NA KŘIŽOVATCE - HISTORIE, SOUČASNOST A PERSPEKTIVY}

Resumé: Komparativni studie nahliži v mezinárodním kontextu na problémy současného technického vzdělávání. Vsímá si upadajici kultury technické vzdělanosti a fenoménu nazývaného paradox technické vzdělanosti. Perspektivy jsou vymezovány vkontextu polytechnického principu a konceptu STEM. Na základě analýzy je navrhováno rozšírení pojmu technická gramotnost o emocionální aspekt. Ve studii je na základě poznatkù ze zahraniči predstavováno moderni pojetí výuky techniky a technologii v rámci základního vzdělávání. Jedná se o širši chápáni a zahrnuje výrobní a průmyslové technologie, konstrukční technologie, elektrotechniku a energetiku, agro- a biotechnologie, zdravotnické technologie, informačni a komunikační technologie, dopravní technologie a další.

Klíčová slova: technická výchova, kultura technické vzdělanosti, STEM, technická gramotnost, paradox technické vzdělanosti, rané dětství.

*Autor pro korespondenci: j.dostal@upol.cz 


\section{1 Úvod}

Technické vzdělávání má na základní, středoškolské i vysokoškolské úrovni ve vzdělávacích systémech všech vyspělých států tradici. Můžeme si povšimnout, že důraz na jeho realizaci kopíruje aktuální společenské potřeby nebo výzvy do budoucnosti, myšleno snahy orientovat společnost určitým směrem tak, aby byla konkurenceschopná. Důkazem toho je i projev amerického prezidenta B. Obamy (2009), který určil vzdělávání v oblasti prŕrodních věd, technologií, techniky a matematiky ${ }^{1} \mathrm{z}$ hlediska vzdělávací politiky za prvořadé a vymezil tři zastřešující priority:

- zvýšení STEM gramotnosti tak, aby žáci uměli kriticky myslet v oblasti př́rodních věd, technologií, techniky a matematiky,

- zlepšování kvality výuky matematiky a přírodovědných předmětů tak, aby američtí žáci již nebyli překonáváni jinými zeměmi,

- rozšiřování STEM vzdělávání a pracovních př́iležitostí pro vyčleněné skupiny, včetně žen a menšin.

V projevu také oznámil vytvoření série partnerství, která aktuálně zahrnují přední společnosti, univerzity, nadace, neziskové organizace a organizace zastupující miliony vědců, inženýrů a učitelů. Jejich úkolem je motivovat a inspirovat mladé lidi po celé unii, aby vynikali v oblasti prŕrodních věd, technologií, techniky a matematiky.

Uvedené skutečnosti se pro nás staly podnětem pro vyjádření aktuálních požadavků na technické vzdělávání v České republice, o což v tomto článku budeme usilovat.

\section{Použité metody}

Při zpracovávání studie byly v souladu s aktuálními př́stupy užívanými v oboru využity následující vědecké metody, srov. N. C. Kettley (2010), M. Bray, B. Adamson a M. Mason (2007), M. G. Lodico, D. T. Spaulding a K. H. Voegtle (2006), L. Cohen, L. Manion, K. Morrison (2003). Především se jednalo o teoretické metody, které spočívaly ve studiu publikovaných vědeckých statí, výzkumných zpráv, kurikulárních dokumentů a strategických vládních dokumentů.

Excerpované poznatky byly podrobeny komparativní analýze a kritickému hodnocení $\mathrm{s}$ cílem usporádat je do souvislostí a nového teoretického rámce. Ve vybraných částech jsme uplatňovali snahu popsat problémy spojené s fenomény, které se vyskytují ve společnosti, resp. vzdělávací teorii i praxi.

Užity byly rovněž analyticko-syntetické př́stupy za účelem porozumění vztahům platným ve vzdělávacích systémech, zejména se zaměřením na technické vzdělávání. Při analýzách byly abstrahovány poznatky marginálního charakteru, což umožnilo jejich interpretaci v nových významech.

\section{Aktuální výzvy pro inovaci a pevné zakotvení technického vzdělávání na základních školách}

Komparujeme-li vývoj v USA a u nás, můžeme si povšimnout paralely, i když s několikaletým posunem. V České republice se stal rok 2015 Rokem průmyslu a technického

\footnotetext{
${ }^{1}$ STEM - Science, Technology, Engineering, and Mathematics.
} 
vzdělávání ${ }^{2}$. Jako by aktuální společenské potřeby v České republice vyžadovaly podobné kroky, které byly dříve realizovány $\mathrm{v}$ USA. Lze pozorovat, že zmiňované společenské potřeby mají tendenční charakter a neustále sílí, průmysl a zejména technická odvětví marně volají po kvalifikovaných pracovnících. Nutno poznamenat, že jejich nedostatek však není dán jen tím, že by se absolventi základních škol a gymnázií v tomto ohledu nevhodně orientovali. Je zapř́̌́ciněn též populačním poklesem, což je zřetelné ze statistik nezaměstnanosti. Počty nezaměstnaných jsou na minimální úrovni ${ }^{3}$. Potřeba změny vyplývá i z rostoucí průmyslové automatizace, jelikož jsou na jednu stranu žádoucí vysoce kvalifikovaní odborníci a na druhou stranu pracovníci, kteří nemusí být specialisté, avšak je vyžadována technická gramotnost a schopnost učit se novým věcem.

Jak zahraniční zkušenosti ukazují, tyto skutečnosti je třeba uvažovat již při kurikulárním plánování na základních, středních a vysokých školách. Mnohé snahy se nevyhýbají ani předškolnímu vzdělávání. Inovace na středoškolské a vysokoškolské úrovni již delší dobu v České republice probíhají, zejména s přispěním Evropské unie proběhla řada pozitivních kroků. Dosavadní stav na úrovni základních škol je třeba podrobit kritice, jelikož technika a technologie stojí na okraji zájmu ${ }^{4}$. Současné kurikulární dokumenty (Rámcový vzdělávací program základního vzdělávání) staví učivo o technice a technologiích na volitelnou úroveň ${ }^{5}$. Tento stav je neúnosný a nadále prohlubuje krizi v oblasti deficitu technické gramotnosti u mladé generace a nemálo se může projevovat i v zájmu o technická povolání ${ }^{6}$. Ve světle STEM je tento výrazný nedostatek ještě zřetelnější, je to, jako bychom postavili př́rodopis, fyziku, chemii nebo matematiku na úroveň volitelného předmětu. Stejně tak, jako moderní společnost vyžaduje jedince matematicky, prrírodovědně, jazykově či jinak gramotné, vyžaduje i jedince technicky gramotné. Vzdělávací systém tomuto však ne zcela napomáhá.

Zástupnou roli $\mathrm{v}$ oblasti technického vzdělávání sehrávají vědecká centra pro volnočasové aktivity, tzv. „science centra“, která jsou v posledních letech budována

\footnotetext{
2 Viz http://www.rokprumyslu.eu

${ }^{3}$ Nezaměstnaní pod touto hranicí jsou zpravidla osoby s věkem, který jim již neumožňuje pružně reagovat na požadavky trhu práce anebo osoby, které dlouhodobě nejeví o zaměstnání zájem.

${ }^{4}$ Význam technického vzdělávání na celoevropské úrovni vyplývá i z dřívější studie T. Kozíka a J. Depešové (2007), ve které podrobněji rozebírají začlenění technického vzdělávání do strategických kurikulárních dokumentů upravujících vzdělávání na základních školách.

${ }^{5}$ Výjimkou jsou informační technologie.

${ }^{6}$ „Současné školství dle rodičů nedokáže budovat v dětech zájem o technické vzdělání, který je pritom podle nich potřeba vytvářet již od základní školy. Chybi nám aktivity, které by na školách dokázaly děti seznámit s technickými obory a rozvijet jejich nadání. Chybi nám propojení ve spolupráci firem a škol, exkurze do průmyslových podniků a intenzivnějši podpora zvyšování zájmu o technicky zaměrené kroužky, řikaji rodiče.“ (D. Vondrák, 2015).

„Sledujeme také se znepokojením, jak se pomalu vytrácí mezi žáky schopnost něco konkrétního vytvořit a vyrobit. Snažime se proto o podporu polytechnické výchovy a technických predmètù nejen na základnich, ale už v mateřských školách. Podporujeme technické zájmové vzdělávání na všech úrovních. Bude to ale pro uchováni přsislovečné tvorivosti a vynalézavosti českého národa stačit?" (M. Rathouský, 2015).

„Zájem o technické vzdělání $v$ dětech podle názoru rodičũ nedokáže budovat ani školský systém a chybi podle nich také propojeni škol s firmami i technicky zaměřné kroužky. “ (D. Vondrák, 2015).
} 
v integračním pojetí $\mathrm{STEM}^{7}$. Děti zábavnou formou pozorují skutečnosti, se kterými by se běžně nesetkaly, nebo řeší úlohy, které vyžadují znalosti a dovednosti z různých oblastí prrírodních věd, techniky a dalších. Při využití tohoto přístupu jsou dětem předkládány úlohy obsahující problémy, které více odpovídají realitě. Jen málokterý problém z každodenního života vyžaduje pouze jeden typ znalostí. Ovšem ani rutinu nelze opomíjet, běžné životní situace nejsou představovány pouze řešením problémů, ale opakujíími se činnostmi. I v této oblasti lze ale působit v rovině rozvoje vědomostí, dovedností, postojové i emotivní. Učíme se tak situace zvládat rychleji a úspěšněji.

Nezbytnost realizace obecně technického vzdělávání ( $\mathrm{v}$ našem pojetí zahrnuje i technologie) je zjevná a měly by jím procházet i dívky. Je nutno ale připustit, že může být předmětem diskuse $v$ jaké podobě a $v$ jakém rozsahu.

Při hospitacích ve školách a diskusích s laickou veřejností se lze setkat $s$ názory, že by se mělo navrátit vzdělávání do dř́vější podoby, myšleno realizovat „pracovní vyučování“ v dřívějším pojetí nebo tzv. „dílny“. Vůči tomuto názoru je třeba vyjádřit negativní postoj. Cožpak jsou dnešní společnosti předkládány stejné výzvy jako v minulosti? Existuje stejná podoba průmyslu? Platí shodné ekonomické principy? Má společnost stejné cíle jako dřive? Nikoliv a proto nelze ani technické vzdělávání vracet do „starých koleji““, ačkoliv by se to mohlo zdát na první pohled lákavé pro svou implementační snadnost a osvědčenost. Je třeba v reakci na aktuální i budoucí výzvy hledat nové cesty, navrhovat nová řešení, ověřovat je a modifikovat. Je třeba vychovat „lidský kapitál“ nové generace, který nalezne uplatnění v náročných oborech s vysokou príianou hodnotou. Je nezbytné též transferovat poznatky a zkušenosti z technologicky vyspělých zemí, jako je Finsko (T. Kananoja, 2009), Kanada (A. M. Hill, 2009), USA (srov. E. W. Dugger, 2009), Japonsko8, Jižní Korea, Tchaj-wan ${ }^{9}$ a vhodné prvky integrovat do našeho vzdělávacího systému.

Za povšimnutí stojí rovněž následující absurdní situace. V USA B. Obama aktivoval veškeré experty na technické vzdělávání, inicioval výzkum, poskytl nemalé finanční prostředky, v České republice oproti tomu ani přes snahy řady pracovišt' aktuálně neexistuje doktorský studijní program „Didaktika techniky“10, v jehož rámci by mohly vznikat

\footnotetext{
7 Jako prŕklady lze uvést Pevnost poznání (http://www.pevnostpoznani.cz), Techmania Science Center (http://techmania.cz), Vida! (https://vida.cz), Svět techniky (http://www.stcostrava.cz), iQLANDIA (http://www.iqlandia.cz).

${ }^{8} \mathrm{~V}$ Japonsku byl do kurikula základní školy dřive zařazen předmět Technologie a vedení domácnosti (Technology and Homemaking), který zahrnoval 11 oblastí (z toho 5 se zaměřuje na: zpracování dřeva, kovovýrobu, stroje, pěstitelství a základy informací). Nově předmět Technologie a vedení domácnosti integruje 5 uvedených oblastí do dvou Technologie a tvorba výrobku (Technology and making artefacts) a Informace a počitače (Information and computer), viz D. Itoh, M. Isobe a S. Yamazaki (2002). Technické vzdělávání na základních školách se opírá o mezinárodní požadavky a je uznáváno jako jedna z významných oblastí vzdělávání v Japonsku (S. Fujikawa a T. Maesako, 2015).

${ }^{9}$ Do kurikula základní školy je zařazen předmět Science and living technology, který má předchůdce v tzv. „ručních pracích“ ("handicraft”, "industrial arts” atp.) - tento předmět má v Tchaj-wanu více než stoletou tradici, srov. D. Itoh, M. Isobe a S. Yamazaki (2002).

${ }^{10}$ A) Je tomu i přesto, že didaktika techniky (uživán je i název „technický výchova“) má na území bývalého Československa silnou tradici. Lze např. doložit práce E. Talafanta (1933), J. Poka (1954), F.
} 
výzkumné práce rozkrývající problémy, které je nutné řešit. Stejně tak, jak už bylo zmíněno, je obecně-technické vzdělávání stále na úrovni volitelného předmětu, který nemusí být do školního plánu zařazen. I přesto na úrovni vědy a výzkumu v oblasti technického vzdělávání není situace kritická. Na pracovištích v Olomouci, Plzni, Praze, Brně, Ostravě a jinde, vznikají cenné práce, které se $\mathrm{v}$ mnohém stávají východisky pro ovlivňování reality na školách, zejména $\mathrm{v}$ kontextu výchovy nových učitelů technického vzdělávání. Jako prríklady lze uvést práce J. Stoffy (2000), J. Kropáče a M. Chrásky (2004), J. Kropáče a J. Kropáčové (2006), Z. Friedmanna (2001), M. Scigiela a P. Scigielové (2003), J. Zukersteina (2012), J. Novotného a J. Honzíkové (2014), P. Ćástkové a J. Kropáče (2015) ${ }^{11}$. Je třeba o akreditaci doktorského studijního programu usilovat tím více, jelikož na Slovensku, které je nám z hlediska podoby vzdělávací soustavy velmi blízké, srov. T. Kozík (2015), tento obor existuje a to vč. možnosti habilitačních a profesorských řízení.

Nastíněné problémy vedou $\mathrm{k}$ cílenému zaměření naší pozornosti na podchycení snah o zkvalitnění technického vzdělávání v České republice a $\mathrm{v}$ mezinárodním kontextu na provedení analýzy, komparace a prezentace klíčových poznatků z oblasti STEM tak, aby došlo $\mathrm{k}$ vytvoření báze pro inovativní kroky ve vzdělávání, které jsou aktuálně zejména ze strany zástupců průmyslu vyžadovány.

\section{Polytechnická výchova - historické i současné tendence v ČR}

Vzdělávání v České republice bylo v minulosti výrazněji ovlivňováno sovětskou pedagogikou. $\mathrm{V}$ té době se $\mathrm{k}$ nám dostal koncept polytechnické výchovy ${ }^{12}$. Jak jsme již v práci (J. Dostál a M. Kožuchová, 2016) naznačili, hlavním posláním polytechnické výchovy bylo spojit teoretické vyučování s výrobní praxí. Jednalo se o tzv. polytechnický princip. Škola se měla stát skutečnou pracovní školou, kde se žáci měli obeznámit s nejdůležitějšími výrobními procesy a naučit se je realizovat. Po vzniku SSSR se polytechnické vzdělávání provádělo formou propojení vyučování s výrobní prací. Základem školské práce měla být výroba, které se žáci měli věnovat 10 hodin týdně, tj. $33 \%$ vyučovacího času. Obsahovou náplní byla řemeslná výroba, nap̌r. kovářství, stolařství, modelářství, soustružnictví, včelařství apod.

Tento model však utrpěl vážné trhliny, jelikož polytechnické vzdělávání se nedá uskutečnit jen mechanickým připojením školy k výrobnímu závodu nebo kolchozu a realizací výše uvedeného. Absolventi nebyli připraveni ani pro výrobní praxi, ani pro studium, projevovala se výrazná nesystematičnost. „Kritika nesystematického vědeckého vzdělávání vedla ke hledání nových prístupĩ. Východiskem byl opačný extrém: odstrañuje se pracovní ráz školy, což se projevilo vyloučením předmètů pracovni povahy z učebnich osnov a žáci se

Zemánka a J. Vachka (1955), Š. Brezovského, Z. Pavlíčka a I. Škáry (1980), M. Scigiela a J. Borovičky (1983), M. Scigiela (1986), Z. Friedmanna (1987), F. Mošny a kol. (1990-91).

B) Aktuálně je možné v České republice sledovat „didaktické obrozeni“", což lze hodnotit velmi kladně. Zásluhu na tomto nese především I. Stuchlíková, T. Janík a kol. (2015), ale taktéž i další oboroví didaktici.

${ }^{11}$ Ze zahraničních publikací lze uvést A. Jones, M. J. de Vries a C. M. Buntting (2009) nebo American Association for the Advancement of Science (1999).

${ }^{12} \mathrm{Na}$ podporu polytechnické výchovy na úrovni teoretické i praktické byl vydáván časopis Polytechnická výchova: měsičník věnovaný theorii a praxi výtvarné, technické a výtvarně estetické výchovy na školách. 
$s$ výrobou seznamovali jen teoreticky. Polytechnizace v obdobi 30. let v SSSR byla spojována nejvice s teoretickým vyučováním fyziky, chemie, biologie a matematiky, kde se žáci seznamovali jen $s$ teoretickými principy výroby. Podobná situace nastala později i v socialistickém Československu“ (tamtéž). Do vzdělávacích plánů základní školy byly v roce 1949 zařazeny předměty pracovně-technického charakteru na podporu polytechnické výchovy, ale už v roce 1953 byly povinné pracovní činnosti zrušeny a do výuky pronikl polytechnický intelektualismus. V roce 1960 však bylo od tohoto ustoupeno a byla vytvořena jasnější koncepce polytechnické výchovy. Nově byl do učebních osnov začleněn předmět „pracovní vyučování“, který měl společně s prírodovědnými předměty zajistit polytechnické vzdělávání žáků. Tato koncepce byla chápána jako přiblížení výrobního procesu žákům prostřednictvím výrobních aktivit zakomponovaných do pracovního vyučování.

Po roce 1989 vzdělávání zapadající do uvedeného rámce postupně začalo ustupovat v tom smyslu, že pracovní činnosti, zejm. ty manuální, byly čím dál více na základních školách upozad’ovány. V rámci kurikula postupně posilovaly předměty zaměřené zpočátku na výpočetní techniku ${ }^{13}$, později již na informatiku. Časové dotace však už neumožňovaly věnovat tolik času technickému vzdělávání, mnohdy byly voleny alternativní vzdělávací obsahy. Uved'me př́klad, v roce 1996 začal platit Vzdélávaci program Základní škola, kam byl začleněn předmět praktické činnosti. Učební plán vymezoval pro předmět praktické činnosti určitou časovou dotaci, avšak umožňoval řediteli školy rozhodnout v 1. - 9. ročníku ZŠ o organizaci výuky a o práci $\mathrm{s}$ tematickými celky $\mathrm{v}$ jednotlivých ročnících $\mathrm{v}$ rámci podmínek školy. Práce technického charakteru tak nemusely být realizovány v žádoucí míre, mohly být převážně voleny tematické celky Práce s počitačem, Pěstitelství, Př́prava pokrmů nebo Svět práce.

Rámcový vzdělávací program z r. 2004 umožnil školám ještě větší autonomii. Nově byla vytvořena vzdělávací oblast Člověk a svět práce, která byla na 2 . stupni rozdělena do osmi tematických okruhů: Práces technickými materiály, Design a konstruování, Pěstitelské práce a chovatelství, Provoz a údržba domácnosti, Prríprava pokrmů, Práce s laboratorni technikou, Využití digitálních technologií, Svět práce. Školy si na tomto základě sestavují vlastní školní vzdělávací program, který může zahrnovat technické vzdělávání jen v minimální možné míře. Tento stav přetrvává dodnes.

V poslední době se však nárazově objevují snahy podpořit polytechnické vzdělávání. V roce 2015 vyhlásilo ministerstvo dotační program Podpora polytechnické výchovy $v$ mateřských a základních školách, v rámci kterého mohlo být mj. pořízeno vybavení nebo provedena obnova vybavení tříd mateřských škol nebo technických dílen základních škol učebními pomůckami pro technické vzdělávání (zejm. ručním nářadím, akumulátorovým elektrickým nářadím, spotřebním materiálem). Zcela jistě lze tyto snahy ocenit, avšak ukazuje se, že nemají širší dopad a je zapotřebí koncepčního řešení na kurikulární úrovni.

Lze si povšimnout, že není zcela jasné, co je v současnosti myšleno polytechnickou výchovou, tedy v aktuálním pojetí, v pojetí, které je prezentováno ze strany MŠMT. Jako by bylo pouhou nálepkou něčeho, co tu již bylo, tedy (obecně) technického vzdělávání. Ani ti, co tento termín použivají, netuší, co jím přesně myslí, zejm. $\mathrm{v}$ čem spočívá ona zvláštnost vyjádřená př̌edponou poly ( $\mathrm{z}$ řec. mnoho). $\mathrm{V}$ rámci výzvy č. 48 zaměřené na podporu

${ }^{13} \mathrm{~V}$ té době byla vytvořena první takto orientovaná učebnice (V. Rambousek, 1997). 
profesního rozvoje učitelů mateřských škol v oblasti podpory polytechnického vzdělávání vymezuje MŠMT smysl polytechnické výchovy následovně: „Polytechnická výchova/vzděláváni rozvíji znalosti o technickém prostredí a pomáhá vytvářet a fixovat správné pracovni postupy a návyky, podporuje touhu tvořit a práci zdárně dokončit. Posiluje zájem o technické obory. Patř́ sem i použivání jednoduchých nástrojü, netradičních materiálů a techniky jejich zpracování.“ (Příloha č. 5: výzvy k předkládání žádostí o finanční podporu z OP VK Oblast podpory 1.3 - Další vzdělávání pracovníků škol a školských zařízení, 2013). Z uvedeného nevyplývá specifičnost polytechnické výchovy v porovnání s (tradiční) technickou výchovou.

Aktuálnější dokument Operační program Výzkum, vývoj a vzdělávání (Verze k 5. 5. 2015) je již konkrétnější. Na s. 11 analyzuje nedostatky ve vzdělávací infrastruktuře a uvádí, že „problémem je rovněž nedostatečné vybavení pro rozvoj polytechnického vzdèlávání na základních školách“ a dále na s. 86, že ,výsledkem intervencí bude: 1. zvýšení zájmu dětí a žáků o studium technických a prírodovédných oborů a motivace uplatnit toto vzdèlání na trhu práce, 2. posileni kreativity, manuální zručnosti a vztahu k př́rodè a technice předškolnich dètí, 3. rozširreni polytechnického vzděláváni a zvýšeni kvality polytechnického vzdělávání na ZŠ, SŠ a vyššich odborných školách ve spolupráci s dalšimi vzdělávacími zařizeními a organizacemi“. Přímo se uvádí, že „Polytechnické vzděláváni zahrnuje technické a přirodovědné vzděláváni včetně environmentálního vzdělávání, výchovy a osvěty a podpory vzděláváni $v$ prírodním prostředi (tamtéž). V tomto smyslu však termín polytechnické vzdělávání neoznačuje nějakou specifičnost technického vzdělávání, ale primárně integrační snahy několika oblastí, mezi kterými sehrává technické vzdělávání vedle ostatních pouze jednu ze složek. Avšak pozitivní je, že alespoň v uvedeném dokumentu je technické vzdělávání stavěno na úroveň ostatních oblastí (př́rodovědné vzdělávání zahrnuje př́rodopis, fyziku a chemii, spory bývají v oblasti matematiky - jedná se spíše o formální vědu), ovšem ve vzdělávací realitě a ani v kurikulárních dokumentech tomu tak není, viz již zmiňovaná volitelnost předmětů. Je tedy skutečným záměrem ministerstva podpořit integraci technického vzdělávání s ostatními předměty, provázat technickou výchovu s vnějším prostředím školy anebo podpořit realizaci technické výchovy označované jako „polytechnická výchova“? Odpověd’ není zcela jednoduché nalézt, tím spíše, pokud v současnosti převážná většina základních škol nemá odborné pracovny pro výuku technické výchovy anebo nejsou adekvátně vybaveny.

V souvislosti s polytechnickou výchovou na základních školách zmiňme alespoň stručně i středoškolské vzdělávání. Na této úrovni má polytechnický princip ve smyslu propojení teorie a výrobní praxe $\mathrm{v}$ podnicích velký význam. Ještě koncem 90 . let minulého století část praxí žáků běžně probíhala v podnicích a u budoucích zaměstnavatelů. Od toho se však na některých školách ustoupilo. Tyto školy se izolovaly a odborný výcvik zajištují v převážné míře vlastními silami. Nově se však ukazuje, že toto řešení vede k odtržení od reality a absolventi zcela nedisponují kompetencemi, které jsou na trhu práce vyžadovány. Proto v ČR úspěšně proběhly pilotážní projekty, které ověrovaly systém, kde teoretická výuka 
probíhala ve škole, praktická výuka ale $\mathrm{v}$ maximální možné míře probíhala $\mathrm{v}$ reálných podmínkách konkrétních firem ${ }^{14}$.

Nově se v systému odborného vzdělávání setkáváme s pojmem sociální partner, kterým může být představitel obce či regionu, kde škola působí, zaměstnavatel a další místní instituce nebo rodiče žákủ. Stále více vnímáme, že spolupráce škol a sociálních partnerů je zásadní podmínkou zlepšování kvality $\mathrm{v}$ odborném vzdělávání. Přestože je tento fakt všem zainteresovaným stranám dobře znám a není zpochybňován, úzká a soustavná spolupráce s lokálními sociálními partnery stále u mnoha škol není z různých důvodů samozřejmostí (srov. NUOV, 2011) $)^{15}$.

\section{STEM - společenský fenomén s průnikem do vzdělávání}

Analýzou literatury dospíváme $\mathrm{k}$ závěru, že koncept STEM byl vyvinut $\mathrm{z}$ vládní politiky v USA (National Science Foundation [NSF] and U.S. Department of Education) v roce 1980. Prvně se bylo v rámci tohoto konceptu možné setkat $\mathrm{s}$ akronymem SMET (Science, Mathematics, Engineering, and Technology). Od toho však bylo postupně upuštěno a v roce 2001 začalo být požíváno označení STEM, viz např. Y. S. George, D. S. Neale, V. Horne and S. M. Malcom (2001).

Pojem STEM má nejednoznačný význam, což se projevuje i u těch, kteří ho používají v rámci své profese. National Science Foundation odkazujna čtyři samostatné a specifické oblasti, které známe jako věda (př́rodní vědy), technologie, inženýrství a matematika. ${ }^{16}$ Stále častěji je STEM vnímáno jako komplex vzájemných implikací mezi uvedenými oblastmi. Jak uvádí M. Sanders (2009, s. 20), „neni to ale tak jednoduché, po staletí se prírodni védy, technologie, inženýrství a matematika vyvíjeli jako samostatné obory a bránily si svá suverénni územi". Bude to stát mnohem větší úsilí, než pouhé postavení písmen (oborů) vedle sebe. M. Sanders (tamtéž) proto vyjadřuje nemalou skepsi nad módností STEM.

Skutečností ovšem je, že fenomén STEM se v celé své šíri dostává i do České republiky. Podobné tendence se vyskytují i v jiných evropských zemích, např. v Německu je užíván pojem MINT (Mathematik, Informatik, Natur-wissenschaft und Technik). V kontextu vzdělávání se však projevuje nekompatibilita, jelikož dotčené oborové didaktiky se u nás prolínají minimálně, rovněž předměty jsou vyučovány odděleně ${ }^{17}$, pomineme-li uplatňování mezipředmětových vztahů a jiné formy integrace.

\footnotetext{
14 Nelze nezmínit duálni systém odborné prípravy v Německu, který je vnímán jako jeden z nejpropracovanějšich - studujicí je ve škole žákem a vedle toho má s podnikem uzavřenou zaměstnaneckou smlouvu.

${ }^{15}$ Celou řadu publikaci k této problematice nalezne čtenár pod odkazem: http://www.nuv.cz/pospolu/publikace.

${ }^{16}$ Bývá kladena otázka, zda jsou informačni technologie zahrnuty pod „Technology“. Není tomu tak zcela, informačni technologie (počítače) jsou v konceptu STEM na pomezí technologií, inženýringu a matematiky. Technologie a inženýring spadaji v našem uspořádáni vzdělávání do předmětu „Technika“ nebo Technická výchova“" (záleži na označení predmětů, které není zcela ustálené).

${ }^{17}$ I zmèna uspořádání kurikula je ale př́pustná, např v souvislosti se školstvím ve Finsku nejde nezmínit tzv. učeni založené na fenoménech (Phenomenon-Based Learning), které je aktuálně rozpracováváno jako jedna z cest transformace tamniho základního vzdělávání. Na úrovni předškolního vzdělávání odkazujeme na dokument Natural and Technical Phenomena in Early Childhood Education.
} 
Běžně se můžeme setkat i s různými mutacemi, mj. uvádíme eSTEM (environmental STEM), iSTEM (invigorating STEM), METALS (STEAM + Logic), STREM (science, technology, robotics, engineering and mathematics), STEAM (science, technology, engineering, art, and mathematics), STEAM (science, technology, engineering and applied mathematics), STREAM (science, technology, religion, engineering, art, and mathematics), GEMS (Girls in Engineering, Math, and Science), STEMM (science, technology, engineering, mathematics, and medicine) nebo AMSEE (Applied math, science, engineering, and entrepreneurship).

\subsection{STEM jako potřeba reakce na nové společenské potřeby}

V roce 2001 byly USA považovány za světové lídry ve vědě, technologiích, inženýrství a odvětvích postavených na matematice (Y. S. George, D. S. Neale, V.Horne and S. M. Malcom, 2001). S vývojem ekonomiky se ale postupně začal projevovat nedostatek pracovních sil a to i přes snahu řešit tento problém udělováním pracovních víz. Předpokládalo se, že jedno z každých tří pracovních míst do roku 2015 bude v USA souviset se STEM (Government Accounting Office [GAO], 2000).

Tato situace vygradovala reakcí úřadů na úrovni vlády a řady expertů na vzdělávání v požadavek na změnu. Nově byl kladen důraz na výzkum zaměřený na technické, prŕrodovědné, matematické a technologické vzdělávání a dále na uplatňování inovativních návrhů v rámci realizace výše zaměřeného vzdělávání s cílem zvýšit nejen počet absolventů, ale i realizovat vzděláním odpovídající aktuálním požadavkům doby.

V první vlně zájmu o STEM se plánovaná a později i realizovaná opatření vztahovala na vysoké školství, až později vyšlo najevo, že jen toto nestačí, že je zapotřebí jít níže, na úroveň stř̌edních a rovněž základních škol ${ }^{18}$, srov. např. L. S. Nadelson, J. Callahan, P. Pyke, A. Hay, M. Dance a J. Pfiester (2013) nebo E. Trnová, J. Trna a J. Škrabánková (2015).

STEM můžeme v tomto pojetí považovat za fenomén, který se týká vládních úřadů (koncipují kurikulum a financují vzdělávání), škol (STEM vzdělávání realizují a spoluvytvářejí jeho konkrétní podmínky), rodičů (ovlivňují zájmy žáků a přispívají $\mathrm{k}$ profesní orientaci), žáků (jsou produkty těchto snah), ale i zaměstnavatelů (pojmenovávají žádoucí kompetence). STEM tedy představuje prostor, ve kterém se setkávají různé zájmy zájmy společnosti, úradů, škol, profesních organizací, jedinců a podniků, které jsou nasměrovány $\mathrm{k}$ růstu společnosti jako celku a zachování jeho ekonomické stability.

\subsection{STEM jako integrační tendence ve vzdělávání}

V rovině snah vyřešit ekonomické problémy světa je zřetelná orientace na vzdělávání, které je vnímáno jako podstatný faktor. Jak již bylo nastíněno, hlavním smyslem STEM je príprava absolventů těchto oborů, zajištění pracovní síly v perspektivních oblastech. Tomu logicky odpovídá podpora studijních oborů na středoškolské i vysokoškolské úrovni, které mají potenciál takového absolventy připravit (vychovat). Nejde tedy ani tak o předměty samotné. Jako další cíle bývají uváděny: zvýšení podílu žen zaměstnaných v oborech STEM

\footnotetext{
${ }^{18}$ Hnutí STEM se projevuje i na úrovni primárního vzdělávání, srov. S. Moomaw, a J. A. Davis (2010).
} 
a kultivace nejlepších odborníků (expertů) pro obory STEM (Best Practices in Elementary STEM Programs, 2012).

Významnou pro zvýšení kvality a počtu absolventů v oblasti STEM se ukázala príprava na úrovni základních škol. Nejen, že sehrává podstatnou roli v rámci profesní orientace, pokládá však základy znalostí, dovedností a postojů, které jsou pro další vzdělávání klíčové. Odborné školy již nemohou suplovat jako „tvưrci“ základních znalostí.

Vyjdeme-li z politik, bylo poukázáno na oblast vzdělávacích předmětů, které nemusí mít z principu didaktickou spojitost. Učivo naplňující koncept STEM může být rozvrstveno i do jiných předmětů, než těch, které jsou v našich podmínkách pro tento koncept typické. Jedno je však jisté, je zapotřebí vzdělávání proměnit, ve směru uspokojení společenských potřeb. Jednou z cest, jak tohoto cíle dosáhnout, je integrace. Mnohdy bývá STEM vnímán jako integrační hnutí vázané na předměty, které tento koncept naplňují. V našich podmínkách můžeme uvést předměty fyzika, př́rodopis, chemie, informatika, technická výchova a matematika. Integrační pojetí STEM je nyní velmi akcentované, srov. J. Labov, A. H. Reid a K. R. Yamamoto (2010). Autoři S. W. Bennett a K. O'Neale (1998) k tomuto uvádějí př́klad: inženýr potřebuje znalosti z různých přírodovědných oborů, matematika a technologie mu poskytují podporu pro konstrukční návrhy a jejich aplikace nebo dále chemik potřebuje zajisté znalosti z oblasti chemie, ale často také dalších př́rodovědných oborů, technologií a matematiky.

\section{Technické vzdělávání jako nezbytná složka základního vzdělávání}

Technika (technologie) ${ }^{19} \mathrm{z}$ počátku vystupovala jako něco člověku více či méně vzdáleného, avšak postupně se včlenila do jeho každodenního života, do života většiny lidí a stala se postupně „neviditelnou“. Nově na ni lze nahlížet jako na integrální součást způsobu života člověka. Povšimněme si však skutečnosti, že je smyslově viditelná v rovině artefaktů, jako jsou mobilní telefony, automobily, počítače atp., obvykle ale není vidět z hlediska znalostí a dovedností, které se váží $\mathrm{k}$ jejímu užívání. S tím vystupuje do popředí potřeba existence technicky gramotné společnosti. Je třeba, aby lidé uměli s technikou žít a aby negativně neovlivňovala jejich životy ${ }^{20}$.

Jak bylo naznačeno, technika nezahrnuje pouze artefakty (produkty), ale také znalosti a procesy nezbytné k jejich vytvoření, užívání a likvidaci. Dotýká se jich také know-what, know-how, design, zručnost, myšlení, emoce, kreativita... Jsou svou povahou multioborové a pokud bychom se o ní snažili učit odděleně od prírodovědných, společenskovědních nebo humanitních předmětů, bude to vždy působit uměle. Jak uvádí dokument Education for

\footnotetext{
${ }^{19}$ Vymezení pojmu technika a technologie se podrobně věnoval J. Stoffa (2003). Technologie chápeme spíše jako širši pojem. Díky uživání těchto pojmů v řadě oblastí lidské činnosti a v různých jazycích však v některých pojetích oba pojmy splývají anebo nejsou hranicemezi nimi př́liš zrretelné. Jak uvádí $\mathrm{F}$. Daneš (1994), v angličtině se užívá slovo technique pouze ve významu „,speciální metoda provádění určité činnosti“, kdežto primární význam slova technika v češtině, totiž „výrobní a pracovní zařízení“, pokrývá v angličtině termín technology, který má ovšem zároveň i význam „postupy zpracování“ (tak jako v češtině). Jinak řečeno, angličtina terminologicky neliší „výrobní prostředky“ a "postupy zpracování“ a obojí nazývá jediným slovem - technology.

${ }^{20}$ Uvést lze např. problematiku kyberšikany, závislostí na počítačových hrách, zdravotní rizika spojená s uživáním techniky.
} 
Engineering (2013), oddělování spíše vyhovuje organizaci školního vzdělávání, nežli dynamickým a tvưrčím vzdělávacím potřebám žáků a praktickým požadavkům společnosti. České kurikulum je však tradičně pojato „předmětově“ a v tomto pojetí lze označit za mylnou představu začlenění učiva vázaného $\mathrm{k}$ technice do ostatních, zejm. prírodovědných předmětů. Mezi prírodními vědami a technikou totiž existuje podstatný rozdíl: „na jedné straně věděni a porozumění, na druhé straně užití těchto vědomostí k něčemu praktickému. Věda vytvář́ predstavy o tom, jak svět funguje, zatímco ideje $v$ technice vyústí v použitelný předmèt. Technika je mnohem starši než věda" (srov. L. Wolpert, 1999). Technika jako obsah vzdělávání podléhá zákonům přírody - může být rozšiřována na základě př́rodovědného poznání, ale rovněž může i př́rodovědné poznání předcházet.

$\mathrm{S}$ ohledem na význam techniky ve společnosti a její blízkost $\mathrm{k}$ řešení praktických problémů je žádoucí, aby byla oblast vzdělávání zahrnující techniku v rámci kurikula pojata jako autonomní předmět, avšak plně provázaný s př́rodovědnými předměty, matematiku, výtvarnou výchovu a dalšími. Česká republika není v kladení nedostatečného důrazu na technické vzdělávání na základních školách výjimkou. Všimněme si situace, na kterou upozorňují J. Hallström, M. Hultén a D. Lövheim (2013) a to, že v organizaci kurikula je školní předmět technika často skrytý mezi prŕrodovědnými předměty a rovněž priorita tohoto předmětu je mezi řediteli škol a politiky nízká. Opakující se požadavky na změnu/akcent technického vzdělávání však nejsou z historického hlediska ničím jedinečné. Ve skutečnosti je snaha ovlivnit výuku o technice mnohem starší než školní předmět sám. Učivo o technice se ve školách objevuje dříve, než byl konstituován samostatný předmět a již tehdy se objevovaly požadavky na inovace.

Nezačlenění obsahu vzdělávání o technice zapříčiňuje odtrženost př́rodovědného a matematického vzdělávání od reálného života a poznatky zůstávají na úrovni teorií, což není žádoucí. Zde poukazujeme na uplatnění polytechnického principu i konceptu STEM. Filozofií moderního technického vzdělávání na základních školách je pojímat ho jako koherentní prostor pro učení (coherent learning area), srov. V. Compton (2009). Jako prostor, kde se při výuce setkávají lidské potřeby a žáci se učí nacházet technická řešení $\mathrm{k}$ jejich uspokojení $^{21}$. Využívají při tom poznatků z ostatních předmětů, např. znalosti prrírodovědných, matematických ale i společenských zákonitostí. Ukazuje se, že z pohledu života jsou významnější technická řešení, která platnost př́rodních a společenských zákonitostí doprovází. Jak již bylo naznačeno, jsou blíže člověku a uspokojování jeho potřeb, znalosti z různých oblastí poznání zde vstupují jako nezbytný a plnohodnotný doplněk, jsou předpokladem pro úspěšná řešení. Školní vzdělávání bez začlenění učiva o technice způsobuje jeho odtrženost od praktického života.

Již dlouho je např́íc světem usilováno o produkt technického vzdělávání na základních školách, který by bylo možné chápat jako technicky gramotného člověka, srov. A. Ingerman a B. I. Collier-Reed (2011), P. Ankiewicz (1995), S. J. van Rensburg, C. P. H. Myburgh a P. Ankiewicz (1996), T. I. Pudi (2007), C. Potgieter (2012). Ukazuje se však, že situace je v kontextu dynamicky se vyvíjejícího světa složitější, jako by podoba vzdělávání nedokázala tak rychle reagovat na nové okolnosti. V oblasti technického vzdělávání není divu, napřr. učivo matematiky nebo fyziky je $\mathrm{v}$ čase stabilnější. Cíl tedy můžeme považovat za relativně

\footnotetext{
${ }^{21}$ Samozřejmě v širších souvislostech - ekologických, ekonomických, sociálních...
} 
stálý, tj. výchova technicky gramotného člověka, avšak obsah pojmu technická gramotnost v konkrétním naplnění doznává změn a to zejm. v souvislosti s novou technikou a způsoby zacházení s ní.

Podobně jako R. A. Dixon (2013) vnímáme technickou gramotnost ${ }^{22}$ jako zásadní formu gramotnosti pro 21. století, srovnatelnou s matematickou, prírodovědnou, informační nebo čtenářskou gramotností. Pojem technická gramotnost je vymezován jako schopnost používat, ř́́dit (ovládat), hodnotit a pochopit technologie (srov. Standards for Technological literacy: Content for the Study of Technology, 2007). Vymezením technické gramotnosti se mj. dále zabývali i N. K. Garcia Ramirez a L. F. Martinez Perez (2015), J. Stofa (1992) nebo J. Kropáč (2004). Poslední dva z uvedených autorů na ni nahlíži jako na soubor schopností v uvedených směrech $^{23}$ : uvědomovat si klíčové procesy v technice (co to je a jak to funguje), umět obsluhovat technické př́stroje a zařízení, umět aplikovat technické poznatky $\mathrm{v}$ nových situacích, neustále rozvíjet vlastní technické vědomosti, dovednosti a návyky, umět využívat technické informace a hodnotit je $\mathrm{e}^{24}$.

Předmět Technika začleněný do kurikula základní školy musí odrážet 4 základní složky, které se v rámci filozofie techniky vyvinuly. Jedná se o techniku jako artefakty, techniku jako znalost, techniku jako aktivity a techniku jako aspekt lidstva (společnosti), srov. C. Mitchman (1994). Opomenutí jen jedné kategorie působí jako neúplnost, jako závažný nedostatek. Všechny tedy musí být zahrnuty do rámce obecně technického vzdělávání, v tomto názoru jsme ve shodě s autory A. Jones, C. Bunting a M. J. De Vries (2013). Standard technické

${ }^{22}$ Vedle tohoto pojmu se lze setkat s obdobnými, např. vědecko-technická gramotnost (srov. M.Kožuchová a J. Pavelka, 2007).

${ }^{23}$ Skutečnosti ukazují, že by bylo vhodné pod technickou gramotnost začlenit i rovinu emotivní, tedy ne jen akcentovat rovinu vědomostí, dovedností a návyků. Jako př́kl. je možné uvést strach z technických objektů (lidé se bojí jaderných elektráren, dívky projevují obavy, mají-li pracovat se soustruhem), projevuje se radost $\mathrm{z}$ dobře vykonané práce nebo z vytvořeného produktu (výrobku), př́p. naopak hněv při nezdaru anebo očekávání ve spojitosti s novými technickými řešeními. Proto je žádoucí pod pojem technická gramotnost zahrnout i následující oblast: - ovládat a rozvíjet emoce při činnosti s technikou anebo $v$ situacich, do kterých technika vstupuje.

${ }^{24}$ Aktuální otázkou v souvislosti s technickou gramotností jsou možnosti jejího měření. Na tento problém se zaměřila řada výzkumníků, povšimněme si však, mimo autorů, kteří se orientovali na měření postojů žáků vůči technice (pupils' attitudes towards technology) - srov. E. Garmire a G. Pearson (2006) nebo L. C. Rose, A. M. Gallup, W. E. Dugger a K. N. Starkweather (2004), alespoň dvou prací. První je od autorů S. Avsec a J. Jamsek (2016), kteří se zabývali návrhem způsobu měření technické gramotnosti žáků ve věku 6 - 18 let. V souladu s E. Garmine a G. Pearson (2006) ověřovali možnost jejího měření jako tří samostatných složek - znalostí, schopností a kritického myšlení a rozhodování. Výsledky provedeného experimentu se ukázaly jako statisticky významné a vyvozují závěr, že měření ve třech uvedených oblastech poukazuje na úroveň technické gramotnosti.

Druhá práce je od autorů M. B. Luckay a B. I. Collier-Reed (2014), kteří staví podstatu jejich nástroje pro měření technické gramotnosti na bázi fenomenografické analýzy (phenomenographic analysis). $Z$ výsledků vzešlo, že technickou gramotnost je žádoucí posuzovat v rámci následujících hledisek. Především je to podstata technologii (nature of technology) - artefakty (pozn.: v našem pojetí je myšlena technika v užším pojetí), aplikace artefaktů, pokrok v oblasti artefaktů, znalosti a dovednosti spojené s užíváním a konstruováním artefaktů a dále řešení problémů ve vazbě na interakci s technickými artefakty - řízení interakce, instruování, problematizace, podmanění (zapojení se). V každé z těchto kategorií byly klasifikovány reakce žáků. 
gramotnosti (Standards for Technological Literacy: Content for the Study of Technology, 2007) člení cíle technického vzdělávání na základních školách do 5 hlavních kategorií: podstata technologií, technologie a společnost, konstruování, schopnosti (resp. znalosti a dovednosti) pro život ve světě plném technologií, a svět designu. Provedeme-li komparaci $\mathrm{s}$ výše uvedeným, je zřetelný překryv.

Technické vzdělávání jako činnost není snadnou oblastí lidského konání, jelikož zahrnuje na jednu stranu formování lidských jedinců a na druhou stranu musí poskytovat volnost, která vytvoří prostor pro vyniknutí kreativity žáka. Analýzou technického vzdělávání dopíváme $\mathrm{k}$ vymezení pěti dimenzí technického vzdělávání:

- lidská (je to cílevědomá činnost, člověk vzdělává člověka, dochází ke vzájemnému kontaktu s cílem transferu znalostí a formování osobnosti),

- sociální (jeho realizace je iniciována, plánována a realizována společností, následně společnost jako celek ovlivňuje),

- procesní (zahrnuje činnost učitele i žáků, jednání, operace s materiály, navrhování, projektování, řešení problémů),

- kontextuální (je vedena v rámci kontextů a omezení - materiální, společenská, časová, geografická popřs. jiná rovina),

- produktová (vede k výsledkům projevujícím se v rovině vědomostní, dovednostní, postojové i emotivní, $\mathrm{k}$ technicky gramotným jedincům).

Nezbytné je zmínit se i o názvu předmětu, který technické vzdělávání na základních školách zastřešuje. Název samotný pravděpodobně nikdy nebude přesně vystihovat to, co vše se v jeho rámci odehrává - vzdělávání, výchova; rovina znalostí o technice/artefaktech, činností s technikou, rozvoj řemeslného umu, vytváření kladného vztahu k práci jako nejvy̌šší lidské hodnotě, rozvoj zájmů, profesní orientace, rozvoj osobnosti žáka a další. To je dáno složitostí techniky a souvislostmi, které se $\mathrm{k}$ ní váží. Nicméně i přesto se přikláníme k pojmu technika ${ }^{25}$ (v zahraničí je užíván i název technologie), třebaže nebude všeobjímající. Uvedené označení zapadá i do konceptu označování dalších předmětů jako jsou matematika, informatika, fyzika atp. Navrhujeme proto ustoupit od dřívějších anebo současných názvů pracovní činnosti, praktické činnosti, dílny, ruční práce, technická výchova, polytechnická výchova, technické činnosti a dalších a používat jednotný název technika.

\section{Diskuse a závěr}

V mnoha ohledech je současný svět paradoxní. Malé děti na řadě míst vyrůstají v obklopení technikou, mají ji doslova na dosah ruky (telefony, počítače, fotoaparáty, kamery, digitální hry... $)^{26}$, a přesto jí mnohem méně rozumí. Nemají žádnou představu o tom, jak věci fungují a jsou v roli prostých konzumentů bez technické gramotnosti. G. Patterson (2016) hovoří o ,paradoxu technické vzdělanosti ${ }^{“}$. Nejde tak ani o to, aby jim rozuměly na úrovni konstruktérů či opravářů, ale měly by vědět, jak ovlivňují jejich životy a utváŕení jejich budoucnost.

Bylo v dostatečné míře poukázáno na to, že je třeba u mladé generace rozvíjet kulturu technické vzdělanosti. Aby to bylo možné, definujeme následující požadavky:

\footnotetext{
${ }^{25}$ Techniku v tomto př́padě chápeme i jako soubor všech technických věd.

${ }^{26}$ G. Patterson (2016) uvádí, že „,rolovat myši se nauči dřive, nežli chodit"“.
} 
- prripravit a implementovat vhodné kurikulum, které umožní v žádoucí míre vytvářet technickou gramotnost a rozvíjet všeobecné technické dovednosti,

- vytvořit a ověrit efektivní vzdělávací strategie - vzdělávací situace, se kterými se děti setkávají, je musí zaujmout a inspirovat k poznávání techniky, žádoucí je vybudit potřebu dalšího bádání a poznávání principů fungování, ale i kreativního užívání techniky,

- prripravit učitele na výuku technických předmětů tak, aby výuka respektovala nejen současné, ale i budoucí výzvy; je třeba se zaměřit na učitele, kteř́ již na školách působí, a dále i na ty, kteří se na učitelské povolání teprve připravují, přičemž v mnohém jsou žádoucí i inovace v pregraduální př́ípravě,

- $\quad$ uplatňovat polytechnický princip a aplikovat koncept STEM v integračním pojetí, jelikož spolupráce školy s partnery působícími v oblasti vědy, techniky a průmyslu je př́nosná, stejně tak jako integrace vzdělávacích obsahů prrírodovědných předmětů, techniky, informatiky a matematiky,

- vybavit patřičně školy materiálními prostředky, jelikož nelze učit moderně a připravovat žáky na budoucí výzvy se zastaralými učebními pomůckami.

Inspirace pro inovace technického vzdělávání v České republice je možné mj. najít $\mathrm{v}$ časopisech vydávaných organizací ITTEA (International Technology and Engineering Educators Association, http://www.iteea.org): Technology and Engineering Teacher, Children's Technology and Engineering a Journal of Technology Education. Za pozornost stojí dokument Standards for Technological literacy : Content for the Study of Technology (2007), který vymezuje oblasti vhodné pro rozvoj technické gramotnosti a dále Advancing Excellence in Technological Literacy : Student Assessment, Profesional Development, and Program Standards (2003), jež z dnešního pohledu přináší cenné poznatky v klíčových aspektech inovativního pojetí technického vzdělávání.

Zmiňovali jsme kurikulum a s ním spojený obsah technického vzdělávání. Povšimněme si v této souvislosti následujícího jevu. Historicky byl vzdělávací obsah zaměřený na počítače součástí technických předmětů (technické výchovy) ${ }^{27}$. S důrazem na uplatňování počítačů v každodenním životě člověka vyvstal požadavek na vytvoření nového předmětu, nejdříve nazývaného Práce s počitačem, Výpočetni technika a později Informatika. Na samotném počátku byla výuka zaměřena na hardware, části počítače, možnosti rozšiřování, sestavování jednotlivých komponentů, programování a obsluhu základních programů. Později se těžiště přeneslo více do roviny ovládání software (tzv. uživatelské pojetí), ale i tvorby webových stránek, jednoduššího programování aj. S ohledem na připravovanou změnu výuky informatiky ${ }^{28}$ se jeví, že se opět přibližuje $\mathrm{k}$ technické výchově, což dokládá článek charakterizující plánované inovace (Dostan̆ včelku domů. Žáci se budou v nové informatice učit, jak myslí počitače, 2016). Ne však ve smyslu možného sloučení předmětů, avšak $\mathrm{v}$ rovině vytváření vhodných př́ležitostí pro mezipředmětovou integraci. Ve zmiňovaném článku se uvádí „Ve školách by se mělo více učit o tom, jak počítače fungují, a hlavně změnit

\footnotetext{
${ }^{27}$ Srov. Vzdělávací program Základní škola (1996).

${ }^{28}$ Potřeba změny v oblasti výuky informatiky vyplývá ze Strategie digitální gramotnosti ČR na obdobi 2015 až 2020 (2015, s. 71), kde se mj. uvádí: „V oblasti vzdělávání a učeni dospělých jsou nedostatečné možnosti ziskání komplexnich kompetencí potřebných pro uplatněnív tzv. digital jobs“.
} 
obsah hodin informatiky. Dnes je hlavní náplní umět použit word či excel. "Po deseti letech je tento model překonaný, řiká ministerstvo.“... ...,Žáci maji v hodinách pracovat i praktičtěji. Dostanou třeba auto ze stavebnice Lego a maji za úkol naprogramovat ho tak, aby jezdilo" (tamtéž). V rámci didaktiky technické výchovy je již však problematika robotických programovatelných stavebnic řešena cca 10 let, což mj. dokládají práce M. Havelky (2006), M. Havelky a Č. Serafina (2012) a M. Havelky a I. Dömischové (2013) a tyto stavebnice jsou v technické výchově na základních školách využívány. Moderní pojetí techniky a technologií v rámci základního vzdělávání (technická výchova) je širší a zahrnuje výrobní a průmyslové technologie, konstrukční technologie, elektrotechniku a energetiku, agro- a biotechnologie, zdravotnické technologie, informační a komunikační technologie, dopravní technologie a další. Pojímá všechny inovace, možnosti a modifikace prírodního a technického prostředí tak, aby vyhovovalo lidským přáním a uspokojovalo potřeby člověka.

Stále se měnící svět proto vyžaduje kontinuální, systematickou a uvědomělou práci na výběru vhodného obsahu a jeho transformaci v učivo technických předmětů. $\mathrm{S}$ tím spojené postupy nejsou snadné a nejsou ani věcí jedince. Je třeba perspektivně hledat konsenzy v oblasti vhodného obsahu vzdělávání i způsobů rozvoje žáků v jeho kontextu. Apelujeme tímto na zrŕzzení předmětové komise pro oblast technického vzdělávání na základních školách s působností na státní úrovni, která bude řešit otázky spojené s návrhy kurikulárních dokumentů a poskytovat řešení odpovídající aktuálním společenským potřebám. Takto je tomu na Slovensku, kde jsou členy komise akademici, pracovníci státních úřadů i zástupci školské praxe: prof. Ing. Tomáš Kozík, DrSc. (UKF Nitra), PaedDr. Jozef Kuzma, PhD. (ŠPÚ Bratislava), prof. PaedDr. Jozef Pavelka, CSc. (PU Prešov), prof. PhDr. Mária Kožuchová (KU Ružomberok), prof. PaedDr. Milan Duriš, CSc. (UMB Banská Bystrica), doc. PaedDr. Danka Lukáčová, PhD. UKF Nitra), PaedDr. Mária Škodová, PhD. (ZŠ Brehy), Ing. Peter Špičan (ŠIOV Bratislava), a Mgr. Ludovít Arvay (Občianske združenie riaditel'ov ZŠ na Slovensku $)^{29}$. Existenci této komise lze hodnotit velmi kladně a jsou zřetelné mnohé výsledky, které již byly promítnuty do kurikulárních inovací a potažmo i školské praxe.

\section{Literatura}

Advancing Excellence in Technological Literacy : Student Assessment, Profesional Development, and Program Standards. (2003). Dostupné z: http://iteea.org/File. aspx ?id $=49529$.

American Association for the Advancement of Science. (1999). Dialogue on early childhood science, mathematics, and technology education. Washington, DC: American Association for the Advancement of Science.

Ankiewicz, P. (1995). The planning of technology education for South African schools. International Journal of Technology and Design Education. Volume 5, Issue 3, pp 245-254. DOI: $10.1007 / \mathrm{BF} 00769906$.

Avsec, S., \& Jamsek, J. (2016). Technological literacy for students aged 6-18: a new method for holistic measuring of knowledge, capabilities, critical thinking and decision-making. International Journal of Technology and Design Education. Volume 26, Issue 1, Pages 4360, DOI: 10.1007/s10798-015-9299-y.

${ }^{29}$ Srov. T. Kozík, J. Kuzma, M. Kožuchová, M. Vargová, J. Pavelka, D. Lukáčová a M. Duriš (2013). 
Bennett S. W., \& O'Neale, K. (1998). Skills development and practical work in chemistry. University Chemistry Education. 2, 58-62.

Best Practices in Elementary STEM Programs. 2012. Dostupné z: http://school.elps.k12 .mi.us/ad_hoc_mms/committee_recommendation/4.pdf

Bray, M., Adamson, B., \& Mason, M. (2007). Comparative education research : approaches and methods. Hong Kong, China: Comparative Education Research Centre, the University of Hong Kong : Springer.

Brezovský, Š., Pavlíček, Z., \& Škára, I. (1980). Metodické pokyny pro technické práce v 7. ročníku experimentálních základnich škol. Praha: SPN.

Cohen, L., Manion, L., \& Morrison, K. (2003). Research methods in education. London; New York: RoutledgeFalmer.

Compton, V. (2009). Yep-we can do that: Technological response to the curriculum 'needs' arising.... Design and Technology Education: An International Journal, 14(1), 21-36.

Částková, P., \& Kropáč, J. (2015). Možnosti rozvoje sebepojetí žáka v technické výchově na primární škole. Journal of Technology and Information Education. Vol. 7. Issue 1. s. 105 113. DOI 10.5507/jtie.2015.009.

Daneš, F. (1994). Technologie versus technika. Vesmír. 73, 657, 1994/11.

Dixon, R. A. (2013). Trends and Issues in Technology Education in the USA: Lessons for the Caribbean. Caribbean Curriculum. Vol. 21, 2013, 47-79.

Dostál, J., \& Kožuchová, M. (2016). Badatelský přistup v technickém vzděláváni: Teorie a výzkum. Olomouc: UP.

Dostaň včelku domů. Žáci se budou v nové informatice učit, jak mysli počitače. (2016). Dostupné z: http://archiv.ihned.cz/c1-65194650-dostan-vcelku-domu-zaci-se-budou-ucitjak-mysli-pocitace

Dostupné z: http://ehrweb.aaas.org/mge/Reports/Report1/AGEP/?downloadURL= true\&loId=EB79A2C2-3280-4404-AAF3-0D5D3F8A9D6D.

Dugger, W. E. (2009). Developments in technology education in the United States of America. In: International handbook of research and development in technology education. Rotterdam: Sense, pp. 65-84.

Education for Engineering. (2013). New principles for design \& technology in the national curriculum. Retrieved from http://www.educationforengineering.org.uk/reports/ pdf/e $4 \mathrm{e}_{\text {_ }}$ report_feb2013.pdf.

Friedmann, Z. (1987). Úvod do didaktiky technické výchovy. Brno: UJEP.

Friedmann, Z. (2001). Didaktika technické výchovy. Brno: MU.

Fujikawa, S., \& Maesako, T. (2015). Present Situation and Problems of Technology Education in Japan: With Focusing on Technology Education as General Education. International Research in Education. Vol. 3, No. 2, September 2015 s. 173 - 182. ISSN 23275499. DOI: http://dx.doi.org/10.5296/ire.v3i2.7576.

Garcia Ramirez, N. K., \& Martinez Perez, L. F. Incidencia del abordaje de una cuestión sociocientífica en la alfabetización científica y tecnológica de jóvenes y adultos. (2015). Prax. Saber [online]. vol.6, n.11, pp. 87-114.

Garmire, E., \& Pearson, G. (2006). Tech tally: Approaches to assessing technological literacy. Washington, DC: National Academies Press. 
George, Y. S., Neale, D. S., Van Horne, V., \& Malcom, S. M. (2001). In pursuit of a diverse Science, Technology, Engineering, and Mathematics Workforce: Recommended Research Priorities to Enhance Participation by Underrepresented Minorities. Dostupné na: http://ehrweb.aaas.org/mge/Reports/Report1/AGEP/.

Hallström, J., Hultén, M., \& Lövheim, D. (2013). The study of technology as a field of knowledge in general education: historical insights and methodological considerations from a Swedish case study, 1842-2010. International Journal of Technology and Design Education. Volume 24, Issue 2, Pages 121-139. DOI 10.1007/s10798-013-9252-x.

Havelka, M. (2006). K možnostem aplikace stavebnic LEGO a prvků DCP Microsense $\mathrm{v}$ rámci výuky $\mathrm{v}$ obecně technicky zaměřených vyučovacích předmětech. In Trendy ve vzdělávání 2006 - Technika a informačni technologie. Olomouc: Votobia, s. 35-39. Havelka, M., \& Dömischová, I. (2013). Spojení konstrukční stavebnice Lego WeDo s projektem Scratch jako jedna $z$ alternativních cest ve výuce algoritmizace a programování na 1. stupni ZŠ. Trendy ve vzdělávání. Olomouc, Votobia, s. 205 - 211.

Havelka, M., Serafín, Č., \& Kropáč, J. (2012). Uplatnění konstruktivistického pojetí při realizaci výuky $\mathrm{s}$ konstrukční stavebnicí LEGO MINDSTORMS ve spojení $\mathrm{s}$ rozšiřujícím setem Tetrix education base set. In Technika a vzdelávanie. Banská Bystrica: UMB, s. 24-26.

Hill, A. M. (2009). The study of technology in Canada. In: International handbook of research and development in technology education. Rotterdam: Sense. pp. 85-92.

Ingerman, A, \& Collier-Reed, B. I. (2011). Technological literacy reconsidered: A model for enactment. International. Journal of Technology and Design Education. Volume 21, Issue 2, pp 137-148. DOI: 10.1007/s10798-009-9108-6.

Itoh, D., Isobe, M., \& Yamazaki, S. (2002). A Comparative Study on Relation Between Science ond Technology Curricula on Northern Ireland, Scotland, Taiwan ond Japan. In Rethinking Science and Technology Education To Meet the Demands of Future Generations in a Changing World. Parana, Brazil: International Organization for Science and Technology Education (IOSTE).

Jones, A., Buntting, C., \& Marc J. de Vries. (2013). The developing field of technology education: a review to look forward. International Journal of Technology and Design Education. Volume 23, Issue 2, pp 191-212. DOI: 10.1007/s10798-011-9174-4.

Jones, A., de Vries, M. J., \& Buntting, C. M. (2009). International handbook of research and development in technology education. Rotterdam; Boston, Mass.: Sense Publishers.

Kananoja, T. (2009). Technology education in general education in Finland. In: International handbook of research and development in technology education. Rotterdam: Sense, pp. 5164.

Kettley, N. C. (2010). Theory building in educational research. New York: Continuum International Pub. Group.

Kozík, T. \& Depešová, J. (2007). Technická výchova v Slovenskej republike v kontexte vzdelávania v krajinách Európskej únie. Nitra: UKF.

Kozík, T. (2015). The Importance of Technical Education for the Development of Society. Acta Technologica Dubnicae. Volume 5, issue 3 DOI: 10.1515/atd-2015-0070. 
Kozík, T., Kuzma, J., Kožuchová, M., Vargová, M., Pavelka, J., Lukáčová, D. \& Duriš, M. (2013). Zmeny a perspektívy technického vzdelávania vo vzdelávacej oblasti Človek a svet práce. Časopis Technika a vzdelávanie. 2, 2013, č. 2. s. 3 -6.

Kožuchová, M., \& Pavelka, J. (2007). Požiadavky na vedecko-technickú gramotnost' absolventa základnej školy. In Absolvent základní školy. Brno: MU.

Kropáč, J. (2004). Technika, technické vědy, technická výchova. In Kropáč, J., Z. Kubíček, M. Chráska a M. Havelka. Didaktika technických predmétů (vybrané kapitoly). Olomouc: UP.

Kropáč, J. a M. Chráska (2004). Výchova v obecně technických předmětech. Olomouc: UP.

Kropáč, J., \& Kropáčová, J. (2006). Didaktická transformace pro technické předměty. Olomouc: UP.

Labov, J., Reid, A. H., \& Yamamoto, K. R. (2010). Integrated Biology and Undergraduate Science Education: A New Biology Education for the Twenty-First Century? Life Science Education. vol. 9, no. 1, s. 10 - 16 DOI: 10.1187/cbe.09-12-0092

Lodico, M. G., Spaulding, D. T., \& Voegtle, K. H.. (2006). Methods in educational research : from theory to practice. San Francisco, CA: Jossey-Bass.

Luckay, M. B., \& Collier-Reed, B. I. (2014). An instrument to determine the technological literacy levels of upper secondary school students. International Journal of Technology and Design Education. Volume 24, Issue 3, pp 261-27. DOI: 10.1007/s10798-013-9259-3.

Mitcham, C. (1994). Thinking through technology. The path between engineering and philosophy. Chicago: Chicago University.

Moomaw, S., \& Davis, J. (2010). STEM Comes to Preschool. YC Young Children. 65.5 (Sep 2010): 12-14,16-18.

Mošna, F., \& kol. (1990-1991). Didaktika základů techniky. Praha: SPN, 2 sv. (269; 310 s.).

Nadelson, L. S., Callahan, J., Pyke, P., Hay, A., Dance, M. \& Pfiester, J. (2013). Teacher STEM Perception and Preparation: Inquiry-Based STEM Professional Development for Elementary Teachers. The Journal of Educational Research. Volume 106, Issue 2, s. $157-168$.

National Science Foundation \& Department of Education. (1980). Science \& Engineering Education for the 1980's and Beyond. (NSF Publication No.80-78). Washington, DC: U.S. Government Printing Office.

Natural and Technical Phenomena in Early Childhood Education. Dostupné na: http://www.ph-ludwigsburg.de/html/8x-0009-s-01//wp-content/uploads/2010/10/ naturbild_buch01.pdf.

Novotný, J. \& Honzíková, J. (2014). Technické vzdělávání a rozvoj technické tvořivosti. Ústí nad Labem: UJEP.

NUOV. (2011). Spolupráce odborných škol s jejich sociálními partnery. Praha: NUOV.

Obama, B. (2009, November 23). President Obama Launches "Educate to Innovate" Campaign for Excellence in Science, Technology, Engineering \& Math (STEM) Education. The White House. Dostupné z: http://www.whitehouse.gov /the-press-office/presidentobama-launches-educate-innovate-campaign-excellence-science-technology-en.

Operačni program Výzkum, vývoj a vzdělávání. (2015). 182 s. Dostupné z: http://www. google.cz/url?sa=t\&rct=j\&q=\&esrc=s\&source=web\&cd=3\&ved=0ahUKEwji7cWqMHLAhXInRoKHagmBRMQFggiMAI\&url=http\%3A\%2F\%2Fwww.kr-karlovarsky.cz 
\%2Fkrajsky-urad\%2Fcinnosti\%2FDocuments\%2FEU_region\%2FOPVVV_FINAL_ 19012015.docx\&usg=AFQjCNEYLqAGCx8VfeodC1 owjo54tQg0Kg\&sig2=yZTyvnhuLH RlC6W507X08w\&bvm=bv.116636494,d.d2s.

Patterson, G. (2016). What children need to know about tech. Dostupné z: http://www.weforum.org/agenda/2016/01/what-children-need-to-know-about-tech

Pok, J. (1954). Školní dilna jako doplněk polytechnické výchovy: Její zařizení a práce $v$ ni. Praha: SPN.

Polytechnická výchova: měsičník věnovaný theorii a praxi výtvarné, technické a výtvarně estetické výchovy na školách. Praha: Státní nakladatelství, 1946-1948.

Potgieter, C. (2012). Linking learning activities and assessment activities to learning outcomes and assessment standards when teaching technology: A case study. International Journal of Technology and Design Education. Volume 23, Issue 4, pp 969-986. DOI: 10.1007/s10798-012-9226-4.

priorities to enhance participation by underrepresented minorities. Report from the

Př́loha č. 5: výzvy k predkládání žádostí o finančni podporu z OP VK Oblast podpory 1.3 Dalši vzděláváni pracovniku škol a školských zařizení. (2013). 12 s. Dostupné z: http://docplayer.cz/4091106-Priloha-c-5-vyzvy-k-predkladani-zadosti-o-financni-podporuz-op-vk-oblast-podpory-1-3-dalsi-vzdelavani-pracovniku-skol-a-skolskych-zarizeni.html.

Pudi, T. I. (2007). Understanding technology education from a South African perspective. Pretoria: Van Schaik.

Rambousek, V., \& kol. (1997). Práce s počítačem: pro 6.-9. ročník základnich škol. Praha: Fortuna.

Rathouský, M. (2015). Komentář: Dnešni absolventi vynikají hlavně sebevědomím. Dostupné z: $\quad$ http://www.rokprumyslu.eu/aktualne/komentar-dnesni-absolventi-vynikaji-hlavnesebevedomim-4167/

Rose, L. C., Gallup, A. M., Dugger, W. E, Jr, \& Starkweather, K. N. (2004). The second installment of the ITEA/Gallup poll and what it reveals as to how Americans think about technology. Technology Teacher, 64(1), 1.

Sanders, M. (2009). STEM, STEM Education, STEMmania. The Technology Teacher. Vol. 68 , N. 4, s. $20-26$.

Science, Technology, Engineering, and Mathematics workforce: Recommended research

Scigiel, M. (1986). Didaktika technické výchovy. Brno: UJEP.

Scigiel, M., \& Borovička, J. (1983). Kapitoly z didaktiky technické výchovy. Brno: UJEP, Scigiel, M., \& Scigielová, P. (2003). Kapitoly z technické zájmové ćinnosti. Brno: Paido.

Standards for Technological literacy : Content for the Study of Technology. (2007). 260 s. Dostupné z: https://www.iteea.org/File.aspx?id=67767\&v=691d2353

Stoffa, J. (1992). O všeobecnej technickej vzdelanosti mládeže. In Technické vzdelávanie jako súčast’ všeobecného vzdelávania. B. Bystrica: UMB, s. 30 - 33. Stoffa, J. (2000). Terminológia v technickej výchově. Olomouc: UP.

Stoffa, J. (2003). Technika a technológia : návrh na odstránenie termínovej kolízie v pedagogike a andragogike. In: Pojmoslovné spory a ich definičné rieąenia vo výchovovede. Bratislava: Stimul, FF UK Bratislava, s. 91-101.

Strategie digitálni gramotnosti ČR na období 2015 až 2020. (2015). 94 s. Dostupné z: http://www.mpsv.cz/files/clanky/21499/Strategie_DG.pdf. 
Stuchlíková, I., Janík, T., Beneš, Z., Bílek, M., Brücknerová, K., Černochová, M., Č́žzová, V., Čtrnáctová, H., Dvořák, L., Dytrtová, K., Gracová, B., Hník, O., Kekule, M., Kostková, K., Kubiatko, M., Nedělka, M., Novotná, J., Papáček, M., Petr, J., Píšová, M., Řezníčková, D., Slavík, J., Staněk, A., Šmejkalová, M., Tichá, M., Valenta, J., Vaníček, J., Vondrová, N., Závodská, R., \& Žák, V. (2015). Oborové didaktiky: vývoj-stav-perspektivy. Brno: MU. Talafant, E. (1933). Výchova technická i estetická jako princip školní práce na škole měštanské a na vyšším stupni školy obecné: náčrtník pro učitele i žáka. Šumperk na Moravě: nákladem J. Vlad. Mangla, 27 stran, 65 listů.

Trnová, E., Trna, J. \& Škrabánková, J. (2015). Fostering STEM giftedness by experimentation in pre-primary and primary education. In 21st World Conference Educating Gifted and Talented Children - Turning Research Into Practice. Odense.

Van Rensburg, S. J., Myburgh, C. P. H., \& Ankiewicz, P. (1996). Curriculum development for technology in South Africa: Gender issues. Paper presented at the GASAT 8 conference, Ahmedabad, India, 5-10 January.

Vondrák, D. (2015). Školy nerozvijeji zájem dětí o techniku, mini rodiče. Dostupné z: http://www.rokprumyslu.eu/aktualne/skoly-nerozvijeji-zajem-deti-o-techniku-mini-rodice$8055 /$

Výtvarná a technická výchova: měsičník věnovaný theorii a praxi výtvarné, technické a výtvarně estetické výchovy na školách všech stup̌̌u. Praha: Státní nakladatelství, 1949.

Wolpert, L. (1999). Je věda nebezpečná? Vesmír. 78, 325, 1999/6. Dostupné na: http://casopis.vesmir.cz/clanek/je-veda-nebezpecna.

Zemánek, F., \& Vachek, J. (1955). O polytechnickom vyučovaní. Bratislava: SPN.

Zukerstein, J. (2012). Aktivizujicí metody v technickém vzdělávání. Ústí nad Labem: UJEP. 